PIOTR GUZOWSKI

Instytut Historii i Nauk Politycznych Uniwersytetu w Białymstoku

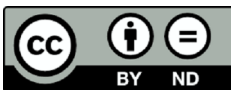

RADOSŁAW PONIAT

Instytut Historii i Nauk Politycznych Uniwersytetu w Białymstoku

\title{
„ŻE ZAŚ W WIEKU CYFR CYFRAMI TYLKO POPRZEĆ MOŻNA TWIERDZENIE..." - RAZ JESZCZE O KONDYCJI POLSKICH BADAŃ NAD HISTORIĄ GOSPODARCZĄ
}

Z satysfakcja przyjęliśmy informację, że nasz tekst Miejsce badań kwantytatywnych we wspótczesnej historiografii polskiej spotkał się $\mathrm{z}$ odzewem $\mathrm{w}$ środowisku badaczy historii gospodarczej, czemu dał wyraz Rafał Matera w polemice pt. Kilka uwag na temat miejsca badań ilościowych w polskiej historiografii gospodarczej. Stan i perspektywy. W dodatku autor podkreślił, że nasz artykuł okazał się kontrowersyjny „wyłącznie ze względu na postawione tezy i niektóre oceny, ale nie ze względu na zawartość merytoryczna”. Rafał Matera przyznał, że zgadza się także „z większością wniosków”, m.in. z tym, że „to ekonomiści znacznie lepiej przyswajają ilościowe podejście w analizie naukowej”, a „zawodowi historycy nie znają owoców pracy z zakresu historii gospodarczej i demografii historycznej (a także ich metod)".

Jednocześnie zaznaczył, że „największy [...] sprzeciw budzi jednostronna ocena kondycji historii gospodarczej umieszczona w podsumowaniu artykułu". Przypomnijmy, że niestosowanie metod kwantytatywnych oraz teorii w badaniach nad historia gospodarczą uznaliśmy za objaw trwającego od kilkudziesięciu lat kryzysu. Zauważyliśmy również pewną izolację bardziej skwantyfikowanych nurtów historiografii, $\mathrm{np}$. historii gospodarczej i demografii historycznej, od pozostałych, nieposługujących się powszechnie liczba, dziedzin uprawianej przez nas nauki, objawiajacca się m.in. publikowaniem przez przedstawicieli historii ilościowej głównie w czasopismach wyspecjalizowanych, branżowych (np. „Przeszłość Demograficzna Polski”, „Roczniki Dziejów Społecznych 
i Gospodarczych"), a nie ogólnych, co skutkuje marginalizacją lub nieznajomością historii gospodarczej i demografii historycznej wśród historyków. Ta właśnie, przyznajemy, że dosyć pesymistyczna, opinia wzbudziła wątpliwości, które w niniejszej odpowiedzi chcielibyśmy rozwiać.

Jako praktycy zarówno historiografii gospodarczej, jak i demografii historycznej staraliśmy się pisać o obu tych dziedzinach w kontekście innych nurtów historiografii, gdyż stosowanie metod ilościowych może mieć szerokie zastosowanie. $\mathrm{Z}$ analiz statystycznych korzystać przecież moga także badacze dziejów politycznych, kultury, wojskowości i wielu innych zagadnień, choć przyznać należy, że w Polsce jest to niezwykle rzadkie zjawisko. Wskazówki metodologiczne w tym zakresie, opublikowane przed kilkudziesięciu laty w dwóch tomach: Historia $i$ nowoczesność. Problemy unowocześnienia metodologii i warsztatu badawczego historyka oraz Metody i wyniki. $Z$ warsztatu historyka dziejów społeczeństwa polskiego, nie spotkały się $\mathrm{z}$ uznaniem $\mathrm{w}$ środowisku ${ }^{1}$. Wygląda na to, że zacytowany w tytule Józef Rolle, lekarz i historyk amator, był bardziej świadomy tego w końcu XIX w. niż zawodowi historycy u progu nowego tysiąclecia ${ }^{2}$.

Skoro polemika Rafała Matery skupia się na historii gospodarczej, wypada zdefiniować, co pod tym terminem my rozumiemy. Rafał Matera słusznie zauważył, że nie jest to pojęcie całkowicie jednoznaczne, nie stoi też za nim tylko jedna szkoła z tylko jedna, właściwą metoda. Z $\mathrm{Z}$ całą pewnością inaczej historię gospodarczą pojmować będzie ktoś zajmujący się dziejami biznesu, inaczej ekonometrysta poszukujący w przeszłości materiału do testowania teorii ekonomicznych, a w jeszcze inny sposób będzie to czynił ktoś piszący głównie o historii myśli ekonomicznej. Gdyby jednak spróbować wskazać cechy wspólne łączące badaczy podzielonych ze względu na specjalności, preferowane epoki, szkoły i lokalne tradycje, kilka elementów powinno się jednak na takiej liście pojawić.

Naszym zdaniem, pierwszym z nich będzie tu związek z teoria, przede wszystkim ekonomiczna, ale też społeczną bądź z zakresu nauk politycznych. Nie chodzi tu, oczywiście, o obowiązkowe istnienie rozbudowanej części teoretycznej w każdej publikacji, ale raczej o wpisanie badań w szerszy kontekst debaty naukowej, stawianie i testowanie hipotez odnoszących się do kwestii mających donioślejsze znaczenie

${ }^{1}$ Historia $i$ nowoczesność. Problemy unowocześnienia metodologii $i$ warsztatu badawczego historyka, red. J. Leskiewiczowa, S. Kowalska-Glikman, Wrocław-Warszawa-Kraków 1974; Metody i wyniki. Z warsztatu historyka dziejów społeczeństwa polskiego, red. S. Kalabiński, współudział J. Hensel, I. Rychlikowa, Warszawa 1980.

${ }^{2}$ J. Rolle, O dziedziczeniu obłakania, „Przegląd Lekarski” 27, 1888, nr 46, s. 609. 
niż tylko pojedyncze studium indywidualnego przypadku. Świadomość teoretyczna autora powinna też stanowić zabezpieczenie przed naiwnym „opowiadaniem źródeł”, opisem służącym samemu tylko opisowi. Kwestii tej poświęcili swoje teksty najwybitniejsi historycy gospodarczy. Jerzy Topolski zwrócił uwagę, że: „Mimo wyraźnego w skali ogólnej poparcia w praktyce badawczej dla naukowego idiografizmu, wybitniejsi przedstawiciele nowej dyscypliny zdawali sobie sprawę z żywotnej potrzeby inspiracji teoretycznych dla historii gospodarczej”3. Carlo M. Cippola na dowodzenie znaczenia teorii poświęcił rozdział w swoim wprowadzeniu do studiów nad historia gospodarczą ${ }^{4}$, a Gary R. Hawke napisał podręcznik ekonomii dla historyków ${ }^{5}$.

Uznanie roli teorii daje też nadzieję, że wyniki takiej pracy będa nadawać się do wykorzystania w badaniach innych historyków, co prowadzi nas do wymogu drugiego: historia gospodarcza musi stosować metodę porównawcza. Rezultaty dotyczące pojedynczego roku, kraju czy przedsiębiorstwa nabierają bowiem sensu dopiero wtedy, gdy zestawimy je z innymi latami, państwami, instytucjami. Tylko wówczas mówić można o kryzysie lub wzroście, specyfice lub jednorodności, poszukiwać strukturalnych lub egzogennych uwarunkowań. Oczywiście, nie każdy historyk jest w stanie objąc swymi badaniami kilka obiektów, czasem specyfika materiału źródłowego lub sama jego obszerność stają tu na przeszkodzie, ale właśnie wtedy z pomoca przyjść mu powinno zakotwiczenie jego pracy w naukowych szkołach, świadomość integrujacych poszczególne publikacje kwestii teoretycznych, zwyczajna znajomość literatury wytworzonej przez naukowców z innych ośrodków i państw. W żadnym też przypadku historyk gospodarczy nie może twierdzić, że skoro on jako pierwszy opisał dzieje jakiejś fabryki czy regionu, to wyników swoich nie może zestawiać z żadnymi innymi badaniami, a jego bibliografia ograniczać się powinna jedynie do publikacji źródłowych i kilku przypadkowo dobranych prac o charakterze ogólnym.

Dokonanie takich porównań staje się z pewnością prostsze w sytuacji, gdy naukowcy sięgaja po zbliżone metody i techniki badawcze, w podobny sposób prezentują swe wyniki. Stan taki najłatwiej można osiagnąć przy pomocy metod ilościowych i może to stanowi częściowa przyczynę ich popularności w historii gospodarczej. Nie jest to jednak powód jedyny - wystarczy tu przywołać znaną uwagę Witolda Kuli:

${ }^{3}$ J. Topolski, Historia gospodarcza a teoria ekonomii, „Kwartalnik Historyczny” 71, 1964, nr 1, s. 80.

${ }^{4}$ C.M. Cippola, Between Two Cultures. An Introduction to Economic History, tłum. C. Woodall, New York-London 1991, s. 55 n.

${ }^{5}$ G.R. Hawke, Economics for Historians, Cambridge 1980. 
„metoda statystyczna nie nadaje się do rozwiązania wszystkich problemów historii gospodarczej, niektóre z nich natomiast tylko nią daja się rozwiązać" . Jeśli więc nawet kwantytatywności nie uznamy za warunek sine qua non, to wciąż będziemy twierdzić, że od dziesięcioleci większość dobrej historii gospodarczej wykorzystuje metody statystyczne $^{7}$, a badacze, którzy tego nie czynia, skazują się w środowisku na izolację lub, w ostateczności, funkcjonowanie na jego marginesie. Musimy zresztą podkreślić, że odwołując się do podstawowych zadań ekonomii, opisujacej przecież gospodarowanie przez jednostkę, organizację czy społeczeństwo zasobami, takie kategorie jak: ziemia, kapitał, praca, ceny, wzrost gospodarczy, inwestycje trudno opisać bez pomocy liczb. Nawet jeśli ktoś czyni obiektem swego zainteresowania „czysta” teorię ekonomiczna, to zawsze fundamentalna rolę w jego rozważaniach pełnią obliczenia. Zazwyczaj też przyczyniają się one również do jej krytycznej weryfikacji.

Przy okazji metod ilościowych, może nieobowiązkowych, ale ułatwiających przynależność do głównego nurtu, wskazać należy na kwestię czwarta, także wprawdzie fakultatywna, ale istotna. Jest nią tworzenie, wykorzystywanie oraz udostępnianie baz danych z zakresu historii społeczno-gospodarczej. Działalność taka nie jest, oczywiście, podejmowana przez każdego historyka, ale jeśli zamiast spoglądać na poziom indywidualny analizować zaczniemy zespoły i szkoły badawcze, szybko ją dostrzeżemy. Tak więc w ostatnich latach najbardziej chyba w historii społeczno-gospodarczej aktywne środowisko z Utrechtu opracowało liczne bazy dotyczące standardów życia, populacji, instytucji; Uniwersytet w Groningen udostępnia i rozwija zestawienia opracowane przez Angusa Maddisona; University of Minnesota nadzoruje gigantyczny projekt IPUMS; Robert Allen z Oxfordu zainicjował digitalizację danych dotyczących cen i płac; najpierw w Instytucie Demograficznym Maxa Plancka w Rostoku, a teraz w Berkeley działa projekt Mosaic; pracownicy Emory University stworzyli bazę dotyczącą handlu

\footnotetext{
${ }^{6}$ W. Kula, Problemy i metody historii gospodarczej, Warszawa 1963, s. 5.

${ }^{7}$ Zjawisko takie obserwować też można w sposób ilościowy - wystarczy wskazać na impact factor lub ministerialną punktację czasopism z zakresu historii gospodarczej, w których z metod kwantytatywnych korzysta się z dużą częstotliwością (wbrew przywołanej przez Rafała Materę opinii Kamila Kowalskiego, „Economic History Review” też należy do tej grupy), z tymi, gdzie statystyczne ujęcia są rzadko spotykane. Konstatacje taka potwierdzają także wspomniane przez Rafała Materę analizy Di Vaio i Weisdorfa, które zostały przedstawione nie tylko w formie working paper, ale też w artykule opublikowanym w „Cliometrice”, czyli piśmie wręcz ortodoksyjnie kwantytatywnym: G. Di Vaio, J. Weisdorf, Ranking Economic History Journals. A Citation-Based Impact Factor Analysis, „Cliometrica” 4, 2010, nr 1, s. 1-17.
} 
niewolnikami... Jest wielce symptomatyczne, że przy tworzeniu tych baz, obejmujacych też ziemie polskie, brali udział historycy polscy, ale albo związani z instytucjami zagranicznymi (jak np. Mikołaj Szołtysek, Mikołaj Malinowski), albo pracujacy na ich zlecenie. Rodzimy projekt Historii Polski w liczbach, w którym zresztą jeden z piszących te słowa przez pewien czas uczestniczył, wciąż sprowadza się do druku książek z zestawieniami statystycznymi, a nie przygotowania elektronicznych baz danych dostępnych wszystkim badaczom choćby na stronie GUS ${ }^{8}$.

Listę przykładów użytecznych baz danych można by jeszcze ciagnąć długo, wskazane tu przykłady wynikają zaś wyłacznie z osobistych doświadczeń badawczych autorów piszących te słowa. Wszystkie takie przedsięwzięcia nie tylko rozszerzaja dostępną nam bazę źródłowa, pozwalaja na łatwiejsze prowadzenie analiz czy stosowanie metody porównawczej. Równie ważna jest tu kontrola wyników uzyskanych przez poszczególnych badaczy, możliwość ich testowania przy dodatkowych założeniach, zachęta do opracowania i wprowadzenia standardów kodowania i przetwarzania danych. W znacznej mierze to właśnie dzięki temu współczesna historia gospodarcza staje się historia globalna, badającą coraz częściej wybrane procesy w skali całego świata, a nie pojedynczych państw, regionów, miejscowości.

Jak w kontekście podanych tu wymogów, dwóch kluczowych i dwóch może nieobowiązkowych, ale ważnych, ocenić należy współczesną polską historiografię gospodarczą?

Można to zrobić na dwa sposoby: metodą ilościową i jakościową. Pierwsza jest szybka i brutalna. Wystarczy odwołać się do wspomnianych przez Rafała Matere i znanych nam, wbrew jego obawom, artykułów Kamila Kowalskiego, Andrzeja Pieczewskiego i Adama Bukowskiego, będących przeglądem publikacji trzech najważniejszych czasopism z zakresu historii gospodarczej, a więc „The Journal of Economic History” (40 pkt. w ocenie MNiSW), „The Economic History Review” (35 pkt.) i „Explorations in Economic History” (35 pkt.) ${ }^{9}$. Okazuje się, że na ich łamach nie ma artykułów badaczy związanych obecnie z krajowym ośrodkiem naukowym, gdyż jedyny z polskich współautorów opublikowanych w szacownych periodykach tekstów, jak stwierdził sam Rafał Matera, zamiast prowadzić badania na uczelni

${ }^{8}$ Co ciekawe, niektóre $\mathrm{z}$ tak wydanych tabel zostały przekształcone w formę elektroniczna przez związanego z Uniwersytetem w Utrechcie Mikołaja Malinowskiego i umieszczone w Internecie. Sam GUS udostępnił część publikacji do pobrania w formacie pdf.

${ }^{9}$ Wszystkie trzy teksty zostały opublikowały w pracy: Przeglad badań nad historia gospodarcza $w$ XXI wieku, red. R. Matera, A. Pieczewski, Łódź 2011. 
trenuje zawodników futbolu amerykańskiego. Podobne brak jest Polaków w nie mniej prestiżowym „European Review of Economic History” (35 pkt.). Z kolei „Journal of European Economic History” (10 pkt.) opublikował w XXI w. jedynie artykuł Marii Boguckiej, choć inni polscy autorzy byli obecni na łamach pisma w latach 60. i 70. ubiegłego stulecia. Sporadyczne pojawianie się polskich autorów na łamach „Continuity and Change" (20 pkt.) wynika przede wszystkim z łączenia przez pismo tematyki gospodarczej z demografią historyczną i wpływem na nie przemian prawa.

Jeżeli uznamy, że metoda kwantytatywna nie jest w stanie uchwycić subtelnej jakości naszych badań nad dawną gospodarka, a już wiemy, że rodzimi historycy nie darzą statystyki szczególną estyma, przejdźmy do analizy jakościowej, biorącej pod uwagę nasze, opisane we wstępie, standardy współczesnej historiografii gospodarczej. Posłużymy się przykładami monografii, prac zbiorowych, syntez czy podręczników chronologicznie bliskich naszym zainteresowaniom, a więc dotyczących okresu do końca XIX w, które zostały powiązane $\mathrm{z}$ hasłem historia gospodarcza w katalogu Biblioteki Narodowej ${ }^{10}$. W związku z tym, że od wielu lat proces wydawniczy związany jest z procedura recenzyjną oraz praktyka wcześniejszego publikowania tekstów niejako przygotowujących właściwa pracę, system powinien gwarantować ich wyższy poziom i bardziej przemyślaną formę niż ma to miejsce w przypadku wielu artykułów. Przytoczone przykłady dotyczą ważnych i docenianych polskich prac naukowych, realizowanych w ramach poważnych projektów, których wartości nie śmiemy podważać ani oceniać kompleksowo, gdyż zrobili to wcześniej kompetentni recenzenci. Pragniemy jedynie wskazać konsekwencje pominięcia w nich odwołania do teorii ekonomicznej, ujęcia statystycznego lub zignorowania metody porównawczej.

Ciekawy przykład złożonych relacji polskiej historii gospodarczej z teorią ekonomiczną stanowić może, przywoływana też przez Rafała Materę, praca dotycząca niemieckich kolei ${ }^{11}$. Książka ta odwołuje się w jasny i przemyślany sposób do teorii, sięga po koncepcje w nauce światowej znane, a nawet cieszące się w niej znacznym prestiżem (bo tak przecież należy ocenić prace Roberta Fogla), zawiera rozbudowany aparat statystyczny. Zwróćmy jednak uwagę, że zachodnie publikacje, które zainspirowały Janusza Myszczyszyna, maja już pięćdziesiąt lat! Minęło już wszak pół wieku, odkąd pojawiła się książka

${ }^{10}$ Wyjątkiem jest tu oczywiście podręcznik J. Szymańskiego, będący podstawową lekturą na studiach historycznych.

${ }^{11}$ J. Myszczyszyn, Wptyw kolei żelaznych na wzrost gospodarczy Niemiec (1840-1913), Łódź 2013. 
kluczowa dla debaty na temat wpływu kolei na rozwój gospodarczy Stanów Zjednoczonych ${ }^{12}$, Fogel i North zdążyli otrzymać ekonomicznego Nobla, a po polsku już trzydzieści lat temu wydano studium tłumaczące założenia New Economic History ${ }^{13}$, a dopiero teraz, w 2013 r. pojawiła się $\mathrm{w}$ naszej historiografii pierwsza kliometryczna monografia. Trudno o lepszy przykład zapóźnienia, a umieszczone na okładce książki stwierdzenie recenzenta: „Autor zastosował nowe metody badacze, tj. paradygmat New Economic History" zaczyna w tym kontekście brzmieć bardzo ironicznie.

Powyższa konstatacja nie jest, oczywiście, zarzutem skierowanym przeciwko samemu autorowi książki, ale wskazuje ona na dystans dzielący polska historię gospodarczą od światowej. W przekonaniu takim utwierdzić też może lektura pierwszego rozdziału wspomnianej pracy, w którym omówiony został proces kształtowania się kapitalizmu w Europie Zachodniej. Pomijając już niejednoznaczność samego pojęcia, które wcale nie musi pokrywać się z interpretacja autora ${ }^{14}$, zaskakuje anachroniczność opisu rewolucji przemysłowej. Z lektury rozdziału czytelnik nie dowie się o dominujących we współczesnej historiografii światowej interpretacjach tego procesu, fundamentalnych pracach Roberta C. Allena, Jana de Vriesa, Jana Luitena van Zandena, Kennetha Pomeranza, Paolo Malanimy czy Joela Mokyra ${ }^{15}$. Pominięcie wyników badań uzyskanych przez tych i innych historyków sprawia, że cały opis przemian gospodarczych zachodzacych w XVIII i XIX w. okazuje się zaskakująco archaiczny i w najlepszym przypadku oddaje zawartość podręczników z lat 80., a nie współczesny stan wiedzy. Trudno wręcz

${ }^{12}$ R. Fogel, Railroads and American Economic Growth. Essays in Econometric History, Baltimore 1964 .

${ }^{13}$ J. Pomorski, Paradygmat „New economic history”. Studium z teorii rozwoju nauki historycznej, Lublin 1985.

${ }^{14}$ Wystarczy tu wspomnieć, czego autor nie czyni, o dobrze w Polsce znanych pracach Fernanda Braudela czy Jerzego Topolskiego, którzy narodziny kapitalizmu umieszczali w innej epoce, a i same zjawisko odmiennie definiowali; por. F. Braudel, Kultura materialna, gospodarka i kapitalizm XV-XVIII wiek, t. 1-3, tłum. M. Ochab i in., Warszawa 1992; J. Topolski, Narodziny kapitalizmu w Europie XIV-XVII wieku, Warszawa 1987.

${ }^{15}$ R.C. Allen, The British Industrial Revolution in Global Perspective, Cambridge 2009; P. Malanima, Pre-modern European Economy. One Thousand Years $\left(10^{\text {th }}-19^{\text {th }}\right.$ Centuries), Leiden 2009; J. Mokyr, The Enlightened Economy. An Economic History of Britain, 1700-1850, New Haven 2009; K. Pomeranz, The Great Divergence. China, Europe and the Making of the Modern World, Princeton 2000; J. de Vries, The Industrious Revolution. Consumer Behavior and the Household Economy. 1650 to the Present, Cambridge 2008; J.L. van Zanden, The Long Road to the Industrial Revolution. The European Economy in a Global Perspective 1000-1800, Leiden 2009. 
zrozumieć, jak dojść mogło do takiego zaniedbania, dlaczego autorowi nie przyszli z pomoca recenzenci wydawniczy pracy?

Zgłoszone tu uwagi, dotyczace przede wszystkim aktualności wykorzystanej w książce literatury, nie oznaczaja, że praca ta nie ma wielu pozytywnych aspektów. Można wręcz stwierdzić, iż na tle znacznej części krajowej produkcji z zakresu historii gospodarczej prezentuje się ona jako jedna z lepszych. Pojawia się w niej teoria, odniesienia do obcojęzycznej literatury. O tym, że postępowanie takie nie jest uznawane za oczywiste przez wielu polskich badaczy, świadczyć może przykład ostatniej monografii Rafała Kowalczyka Rozwój przemystu ciężkiego w Królestwie Polskim w latach 1877-191416. Choć jej tytuł sugeruje dość szeroki zakres tematyczny, poświęcona została ona przede wszystkim udziałowi kapitału zagranicznego w przemyśle ciężkim Królestwa Polskiego. Podstawę analizy stanowiły głównie zestawienia statystyczne pochodzące $\mathrm{z}$ ówczesnej prasy, zaprezentowane $\mathrm{w}$ piętnastu tabelach, z których części autor zreszta nawet nie omówił, a zamiast tego skupił się na opowieści o działalności poszczególnych przedsiębiorstw. Czytelnik szybko zauważy, że każdy z rozdziałów kończy się 1-2 stronami podsumowania, w których podkreślona zostanie przewaga zaprezentowanych w książce opisów nad pracami z lat wcześniejszych. Podczas gdy stare publikacje miały być obciazżone materializmem historycznym, nowe ujęcie wolne jest od tego grzechu, przeprowadzona zaś przez Kowalczyka analiza prasy dostarczyła nam świeżych, ważnych danych. Pomijając kwestię, czy zaprezentowane w książce zestawienia statystyczne naprawdę uznane być mogą za nowatorskie, przełomowe i wykraczające poza to, co już dawno temu napisali Juliusz Łukasiewicz i Wiesław Puś ${ }^{17}$, skupmy tu uwagę na wykorzystanej $\mathrm{w}$ pracy teorii, odniesieniach do zagranicznych publikacji oraz metodzie porównawczej. Niestety, w każdej z tych kwestii książkę poddać trzeba krytyce. Teoria ekonomiczna jest w niej nieobecna. Współczesna literatura obcojęzyczna sprowadza się do pięciu publikacji autorstwa „historyków radzieckich”, całkiem zresztą wiekowych i przywoływanych jedynie w kontekście wydarzeń zachodzących w przemyśle Królestwa Polskiego ${ }^{18}$. Przy braku nawiązań do prac obcych trudno się

${ }^{16}$ R. Kowalczyk, Rozwój przemystu ciężkiego w Królestwie Polskim w latach 1877-1914, Warszawa 2013.

${ }^{17}$ J. Łukasiewicz, Przewrót techniczny $w$ przemyśle Królestwa Polskiego $w$ latach 1852-1886, Warszawa 1963; W. Puś, Przemyst Królestwa Polskiego w latach 1870 -1915. Problemy struktury i koncentracji, Łódź 1984.

${ }^{18}$ Do tego dochodzi jeszcze jedno hasło biograficzne z niemieckiego słownika i rosyjskojęzyczny artykuł samego Kowalczyka. 
dziwić, że jakiekolwiek porównania z innymi państwami w książce się nie pojawiaja.

Wspomniany powyżej brak odniesień do sytuacji panujacej poza granicami Królestwa okazuje się być brzemienny w skutkach na kilka sposobów. Przede wszystkim prowadzi do poważnego zawężenia podstawy źródłowej. Dobrze można to dostrzec na przykładzie często stosowanego przez Rafała Kowalczyka słowa „lukratywny”, które ma oddawać opłacalność jakiegoś przedsięwzięcia. Z książki nie dowiemy się niczego o stopie zwrotu inwestycji, kalkulacjach kosztów, relacji między środkami reinwestowanymi i z przedsiębiorstw wyprowadzanymi. Czytelnikowi zaprezentowany zostaje natomiast antropomorfizowany kapitał (niemiecki, francuski, polski), który miał czegoś chcieć, do czegoś dążyć. A przecież, nawet jeśli, jak twierdzi autor, zniszczenia wojenne sprawiły, że w Polsce brak jest materiałów archiwalnych pozwalających na analizę uwarunkowań decyzji podejmowanych przez poszczególne grupy kapitałowe, to moga one istnieć w innych państwach. Inwestujące w Królestwie Polskim banki, spółki i towarzystwa swe centrale oraz akcjonariuszy miały przecież we Francji lub Niemczech. Trafiać do nich musiały sprawozdania, zestawienia zysków i strat, tam też zapadały strategiczne decyzje. Czy mamy uwierzyć, że w archiwach koncernu Siemensa nie ma żadnych informacji na temat działalności jego nadwiślańskiego przedstawicielstwa? Francuskie banki i wspierajacy je rząd nigdy nie dowiedziały się, jaki zysk przyniosły ich inwestycje? Jeśli przepływy kapitału maja charakter międzynarodowy, taka też powinna być ich analiza.

Po drugie, rozwój przemysłowy Królestwa Polskiego nie odbywał się przecież w oderwaniu od sytuacji panujacej w innych państwach. Zjawiska takie jak międzynarodowa konkurencja, walka o rynki zbytu, transfer technologii czy stanowiące wszak temat pracy inwestycje zagraniczne włączały go w procesy zachodzące w skali jeśli nie całego globu, to już na pewno Europy. W konsekwencji ograniczenie narracji tylko do wydarzeń krajowych, sugerujące, że przemiany obserwowane w Królestwie miały endogenny charakter, prowadzi do spaczonego obrazu przeszłości.

Wreszcie po trzecie, w ekonomii i historii gospodarczej toczy się ożywiona debata na temat roli, jaką inwestycje zagraniczne odgrywać mogą w rozwoju gospodarczym. Znaczna część powstałych w jej wyniku analiz skupia uwagę na współczesności, ale pojawiły się też prace dotyczące przeszłości. Wystarczy tu wskazać na artykuły Kennedy'ego, Pollarda, Harveya i Taylora czy Wilkinsa ${ }^{19}$. Rafał Kowalczyk ani słowem

${ }^{19}$ W.P. Kennedy, Foreign Investment, Trade and Growth in the United Kingdom, 1870-1913, „Explorations in Economic History” 11, 1974, nr 4, s. 415-444; S. Pollard, 
o tych pracach nie wspomina, może wręcz nie jest świadom ich istnienia, skoro zaznajomienie $\mathrm{z}$ nimi powinno skutkować odmienną prezentacją zgromadzonego przez niego materiału, odniesieniem do teorii ekonomicznej, wykorzystaniem metod ilościowych. Brak nawiązania do badań zachodnich implikuje nie tylko niższą wartość merytoryczna pracy, ale prowadzi też do zaprzepaszczenia szansy na włączenie uzyskanych w niej wyników do międzynarodowego obiegu naukowego. Tak więc zamiast książki na ważny temat, która wpisać się może w światową debatę dotycząca znaczenia inwestycji zagranicznych dla rozwoju gospodarczego, otrzymaliśmy monografię mogąca zainteresować tylko rodzimych badaczy, ignorującą szerszy kontekst analizowanych procesów i niekorzystająca z kluczowych źródeł.

Co ciekawe, o kilka lat wcześniejsza praca habilitacyjna Rafała Kowalczyka zasługuje na zupełnie inną ocenę ${ }^{20}$. Autor odnosił się w niej do współczesnej literatury zachodniej, rozszerzał perspektywę czasowa i terytorialną swych analiz, co pozwalało na dokonywanie porównań ${ }^{21}$. Dwa podstawowe kryteria oczekiwane przez nas od prac z zakresu historii gospodarczej zostały więc tu w jakimś stopniu spełnione i choć w monografii zabrakło aparatu statystycznego (trudno uznać za taki jedną tabelę), to wciąż pozytywnie wyróżnia się ona na tle większości krajowej produkcji. Pojawia się jednak pytanie, dlaczego Rafał Kowalczyk w swej kolejnej pracy już takiego trudu nie podjał? Wydaje się, że odpowiedzi udziela tu ekonomia. Skoro środowisko naukowe, uosobione w tym wypadku zwłaszcza przez recenzentów, nie stawia właściwych wymagań przed autorami i aprobuje prace o dyskusyjnej wartości, zachodzić będzie psychologicznie zrozumiały proces ograniczania wysiłku i obniżania jakości monografii do najniższego, ale jeszcze dopuszczalnego poziomu. W ten sposób słaba produkcja naukowa uznana być może równocześnie za wynik racjonalnego wyboru jej autorów, ale jednocześnie stanowi zarzut stawiany całemu środowisku.

Capital Exports 1870-1914. Harmful or Beneficial?, „Economic History Review” (dalej: EHR), t. 38, 1985, nr 4, s. 489-514; C. Harvey, P. Taylor, Mineral Wealth and Economic Development. Foreign Direct Investment in Spain, 1851-1913, EHR, t. 40, 1987, nr 2, s. 185-207; M. Wilkins, The Free-Standing Company 1870-1914. An Important Type of British Foreign Direct Investment, EHR, t. 41, 1988, nr 2, s. 259-282.

${ }^{20}$ R. Kowalczyk, Polityka gospodarcza $i$ finansowa Księstwa Warszawskiego w latach 1807-1812, Łódź 2010.

${ }^{21}$ Ich zakres nie jest jednak tak wielki jak można by mieć nadzieję, zwłaszcza w kontekście łatwego dostępu do wyników prężnie na Zachodzie prowadzonych prac dotyczących finansów państw nowożytnych. Część z nich udostępniona zresztą została w ramach projektu European State Finance Database. 
Dosyć spektakularnym przykładem samoizolacji nauki polskiej jest rozpropagowana przez monumentalną syntezę Józefa Szymańskiego Nauki pomocnicze historii teoria trofy jako wskaźnika siły nabywczej pieniądza. Została ona sformułowana i opublikowana już w $1958 \mathrm{r}$. przez Zbigniewa Żabińskiego ${ }^{22}$, a w syntetycznym ujęciu scharakteryzowana następująco: „Na trofę składa się koszt normy podstawowego wyżywienia człowieka, służącego odtworzeniu sił pracującego człowieka. Wyżywienie takie to 3000 kalorii, do czego arbitralnie dodaje się $20 \%$ na koszt gotowania, skromnego przyprawiana żywności, koszt substancji mineralnych itp." ${ }^{23}$ A więc w kolejnych wydaniach podręcznika, który czytają wszyscy studenci historii już na pierwszym roku, mamy informacje, że: „Wiele nadziei zdaje się można wiązać z propozycją Zbigniewa Żabińskiego", która w rzeczywistości jest koncepcja archaiczna, nieużywana poza Polską (i Zbigniewem Żabińskim), majacą fundamentalne braki metodologiczne (np. dosyć swobodne dobieranie składników diety, płac itd.) i niedającą materiału porównawczego, gdyż zachodnia historiografia powszechnie posługuje się modelem wypracowanym przez Roberta Allena ${ }^{24}$. I z jednej strony powinniśmy docenić, że Żabiński wyprzedził naukę światową w chęci tworzenia metod porównania standardów życia w przeszłości, a z drugiej skonstatować smutne efekty braku konfrontacji z nauką światowa. Czy mamy bowiem być dumni z tego, że rodzimi naukowcy za każdym razem sami próbuja na nowo wynaleźć koło zamiast sięgnąć po już sprawdzone wzory i je weryfikować twórczo? Czy powinniśmy też ignorować fakt, że zazwyczaj udaje im się doprowadzić do powstania tylko części takiego koła lub całego, ale za to kwadratowego?

Andrzej Wyczański, z którego szkoły się wywodzimy, powtarzał na seminarium, że badanie historii Polski w oderwaniu od europejskiej ogranicza nasze możliwości oceny badanych zjawisk. Tymczasem w tomie poświęconym fundamentalnemu problemowi Klasztoru $w$ gospodarce średniowiecznej $i$ nowożytnej nie podjęto próby komparatystki, a metody kwantytatywne nie zostały użyte do udowodnienia

${ }^{22}$ Z. Żabiński, Biologiczny wskaźnik siły nabywczej pieniadza, RGSG, t. 20, 1958, s. $37-51$.

${ }^{23}$ J. Szymański, Nauki pomocnicze historii, wyd. 6, Warszawa 2005, s. 562.

${ }^{24}$ R.C. Allen, The Great Divergence in European Wages and Prices from the Middle Ages to the First World War, „Explorations in Economic History” 38, 2001, nr 4, s. 411-447; tenże, Progress and Poverty in Early Modern Europe, EHR, t. 56, 2003, nr 3, s. 403-443; R.C. Allen, J.-P. Bassino, D. Ma, C. Moll-Murata, J.L. van Zanden, Wages, Prices, and the Living Standards in China 1738-1925, in Comparison with Europe, Japan and India, EHR, t. 64, 2011, Supplement, s. 8-38. 
jakiejkolwiek tezy badawczej. Redaktor publikacji, Marek Derwich, słusznie zwrócił uwagę we wstępie na konieczność sięgnięcia „do mało dotychczas wykorzystywanych źródeł rachunkowych, statystycznych, inwentarzowych czy powizytacyjnych" ${ }^{25}$, ale okazało się, że metody ich analizy (z wyjątkami!) sa raczej historykom na co dzień zajmujących się życiem monastycznym nieznane. Większość z nich uznała, że najlepszym sposobem na prezentację wyników jest egzemplifikacja. Zamieszczona na końcu książki bibliografia wskazuje, że autorzy tomu, opisującego przede wszystkim podstawową dla wielu klasztorów gospodarkę rolna w okresie wczesnonowożytnym, nie zaglądali do prac Jerzego Topolskiego, Leonida Żytkowicza, Aliny Wawrzyńczykowej, a z fundamentalnych prac Andrzeja Wyczańskiego skorzystał tylko Maciej Zdanek. Na autorytet Witolda Kuli i Jana Rutkowskiego powołano się jedynie, by uzasadnić, skądinąd oczywiste w badaniach gospodarczych, wykorzystanie inwentarzy. Dlatego w książce znaleźć można szereg oryginalnych, jak sądzimy intuicyjnych, podejść badawczych. Na przykład chęci zbadania wydatków słynnej ksieni Mortęskiej towarzyszy komentarz autora artykułu, który z rozbrajająca szczerością wyznał, że wydawca jego źródła pominał ... rachunki, gdyż „na ogół powtarzały się" ${ }^{26}$. W innym tekście - o pobożnych legatach jako źródłach dochodów klasztornych - znajdujemy cztery wykresy prezentujace liczbę donacji, ale żadnego określającego ich wartośćc ${ }^{27}$. Brak statystycznych zestawień owocuje w innym tekście ogólnikowymi stwierdzeniami w stylu: „Przychód roczny klarysek wynosił od kilkunastu do kilkudziesięciu tysięcy złotych" ${ }^{28}$, bez choćby podjęcia próby zestawienia bilansu dla sondażowych lat, co jak na tytuł Obrót gotówka w klasztorze... może się wydać pewnym mankamentem. Podobnie zawieszone w próżni wydaje się stwierdzenie: „Nie ulega wątpliwości, iż dochody bernardynek z klasztoru św. Agnieszki nie były zbyt wielkie" przy braku zestawienia tych dochodów w artykule pt. Źródta utrzymania klasztoru bernardynek... Rażące jest skupianie się na jednym źródle, zazwyczaj proweniencji

${ }^{25}$ M. Derwich, Wstep, w: Klasztor $w$ gospodarce średniowiecznej i nowożytnej, red. M. Derwich, Wrocław 2013, s. 16.

${ }^{26}$ W. Rozynkowski, Na co ksieni Magdalena Mortęska wydawała pieniadze? O wydatkach benedyktynek w świetle „Kroniki benedyktynek chetmińskich”, w: tamże, s. 294.

${ }^{27}$ E. Piwowarczyk, Pobożne legaty jakoźródło dochodu klasztoru bernardynów w Krakowie w latach 1453-1530, w: tamże, s. 209-228.

${ }^{28} \mathrm{P}$. Gasiorowska, Obrót gotówka w klasztorze żeńskim na przykładzie osiemnastowiecznych ksiag rachunkowych wybranych klasztorów krakowskich i lwowskich, w: tamże, s. 312 . 
klasztornej, bez odwołania się do materiałów wytworzonych w pozaklasztornej przestrzeni gospodarczej, w której zgromadzenie duchownych przecież też funkcjonowało. A jeśli już sięga się po źródła np. skarbowe, wówczas robi się to mechanicznie, czytając spisy poborowe bez znajomości uniwersałów podatkowych. W konsekwencji wymyśla się teorie na temat różnic między poszczególnymi rejestrami, które przecież w jednoznaczny sposób wyjaśnia sam prawodawca. W rezultacie, niestety, aby powiedzieć coś o budżecie klasztoru i jego gospodarce trzeba prawie wszystkie badania przeprowadzić jeszcze raz, właśnie przy wykorzystaniu metodologii historii gospodarczej, w tym technik statystycznych. Nie oznacza to oczywiście, że zawarte w opisywanej książce artykuły są bezwartościowe. Wręcz przeciwnie, ich autorzy, wykonując żmudne prace źródłoznawcze, wskazali na istnienie znakomitych i szerzej nieeksploatowanych materiałów, które potencjalnie mogą stanowić podstawę znakomitych studiów. Szkoda jednak, że badacze dziejów klasztorów, odkrywając całe ciagi rachunków, nie zdawali sobie w pełni sprawy z możliwości, jakie dają one w zakresie badań nad gospodarka, gdyż nie wiedza, czym zajmuje się historiografia gospodarcza i jakimi metodami się posługuje.

Brak tej świadomości i towarzysząca im niechęć do badań nad gospodarką ma wiele przyczyn, które częściowo opisali już Jacek Kochanowicz i Anna Sosnowska ${ }^{29}$. Jest to wypadkowa zarówno trendów światowych, jak i jednak - wbrew temu, co pisze Rafał Matera - konsekwencji związanych ze szczególną rolą historiografii gospodarczej w PRL. I nie chodzi tylko o negatywne postrzeganie podatności historyków gospodarczych na indoktrynację, ponieważ w nauce funkcjonowali i tacy, którzy nie uzasadniali tez na polityczne zamówienie. Powody, dla których w pewnym momencie cała generacja historyków odeszła od gospodarki na rzecz dziejów społeczeństwa, kultury czy metodologii, zapewne wymagaja głębszych studiów z zakresu historii historiografii. Widoczna już w latach 80. niechęć do historii gospodarczej zaowocowała jednak wycofaniem jej z programów studiów historycznych na przełomie stuleci. Poważnej redukcji uległo też nauczanie statystyki, na większości uczelni powiązanej z demografią $\mathrm{w}$ jeden, trzydziestogodzinny przedmiot. W takiej sytuacji trudno się dziwić, że młodzi badacze są bardzo słabo przygotowani do analizy zagadnień gospodarczych, a jeśli już się tego podejmuja, robią to na wyczucie, w oderwaniu od współczesnych trendów i nieuchronnie popełniając ogromną ilość błędów. Dlatego

${ }^{29}$ J. Kochanowicz, A. Sosnowska, Historia gospodarcza polski przedrozbiorowej porzucone terytorium, RDSG, t. 71, 2011, s. 7-32. 
określenie historii gospodarczej Polski okresu przedrozbiorowego jako porzuconego terytorium jest trafne i usprawiedliwione.

Zapewne w nieco lepszej kondycji, o czym przekonuje Rafał Matera, głównie za sprawa pracowników katedr historii gospodarczej funkcjonujących w ramach wydziałów ekonomicznych, jest gospodarcza historiografia XIX i XX w. Rację też ma nasz Szanowny Polemista, że środowisko to jest bardzo zintegrowane, czemu bez watpienia służa zarówno coroczne Wrocławskie Spotkania z Historią Gospodarcza, jak i działalność Polskiego Towarzystwa Historii Gospodarczej. Przyjmując jednak wyżej opisane standardy nowoczesnych badań w naszej dziedzinie, możemy wyrazić tylko nadzieję, że wzrostowi liczby badaczy będzie towarzyszyło dążenie do sprostania wymaganiom współczesnej nauki. Konieczność pracy dydaktycznej na kierunkach ekonomicznych powinna sprzyjać stosowaniu teorii ekonomicznej, wymuszać pewien synkretyzm interdyscyplinarny, szersze stosowanie metod kwantytatywnych. Wątpliwości co do tego, czy tak się dzieje, ma sam Rafał Matera, przyznajacc, że większość badaczy historii gospodarczych zalicza się do kategorii „tradycyjnych”. Wskazana przez niego lista badaczy kwantytatywnych jest dosyć krótka. Przywoływane podręczniki historii gospodarczej (dla ekonomistów) oczywiście wypełnione są tabelami i wykresami, ale gdyby spojrzeć na źródła prezentowanych danych to większość pochodzi z dawnej historiografii. Na fakt ten zwracali już zresztą uwagę Jacek Kochanowicz i Anna Sosnowska ${ }^{30}$. Podobnie o niedostatkach prowadzonych współcześnie badań świadczyć też może fakt, iż autorzy wydanego w 2006 r. gospodarczego tomu Historii Polski $w$ liczbach na 15 stronach bibliografii ${ }^{31}$, stanowiącej podstawę do zawartych w pracy tabel, niezwykle rzadko powołują się na publikacje pochodzace z lat 90. lub nowsze. Czy brak ten przypisać należy lenistwu redaktorów, którzy nie chcieli uwzględnić najświeższej literatury, czy raczej uwiądowi badań podstawowych, niezapewniających nowych wyników? Biorąc pod uwagę, kim byli autorzy tomu ${ }^{32}$, ich wysoką pozycję $\mathrm{w}$ świecie akademickim oraz częste pełnione obowiązki recenzentów, sądzić należy, że byli oni dobrze zaznajomieni z wynikami najnowszych prac naukowych, a brak cytowania wynikał z niedostatku badań.

Gwoli ścisłości wskazać też trzeba na prace niewpisujące się w opisane powyżej prawidłowości. Pierwszą z nich jest wydana niedawno

${ }^{30}$ Tamże, s. 28-29.

${ }^{31}$ Historia Polski w liczbach, t. 2: Gospodarka, red. A. Jezierski, A. Wyczański, Warszawa 2006, s. 679-693.

${ }^{32}$ Nadzór merytoryczny nad poszczególnymi rozdziałami pracy pełnili: Andrzej Wyczański, Julian Łukasiewicz i Andrzej Jezierski. 
monografia Cecylii Leszczyńskiej dotycząca polityki monetarnej II Rzeczypospolitej ${ }^{33}$. W jej wypadku czytelnik bez trudu odnajdzie teorię ekonomiczna, perspektywę porównawczą oraz analizę statystyczna. Praca ta jednak tak bardzo odróżnia się od większości krajowej produkcji z zakresu historii gospodarczej, że Rafał Matera nawet o niej nie wspomniał w swoim zestawieniu ważnych publikacji z tej dziedziny. Ciekawie prezentuje się też książka Wojciecha Pacho poświęcona innowacjom w społeczeństwach przedprzemysłowych, która jednak trudno uznać za pracę z nawet bardzo szeroko pojmowanej historii gospodarczej, skoro stanowi ona oderwane od empirii ćwiczenie z teorii ekonomicznej ${ }^{34}$. Publikacje te oraz kilka innych mniejszych studiów znajduja się jednak na marginesie krajowych badań. Jak już zresztą zauważyliśmy, symptomatyczny jest fakt pominięcia ich przez samego Rafała Materę.

Sądzimy, że powyższe przykłady wyraźnie wskazują na złą sytuację, w jakiej znajduja się polskie studia nad dziejami gospodarczymi. Jak to powyżej opisywaliśmy, wśród objawów kryzysu wymienić można: odrzucenie przez rodzimych badaczy teorii, niewykorzystywanie metody porównawczej, brak projektów związanych z tworzeniem baz danych, słaba recepcję polskich prac $\mathrm{w}$ nauce międzynarodowej. Zanik badań kwantytatywnych nie jest więc, wbrew opinii Rafała Matery, jedynie wynikiem funkcjonowania specyficznej „polskiej szkoły historii gospodarczej”35, to jeden z przejawów generalnego kryzysu.

Nasz pogląd o nieistnieniu oryginalnej, rodzimej szkoły niekwantytatywnych badań nad dziejami gospodarczymi może części czytelników wydać się nazbyt surowym, ale obserwując stan obecny, trudno dość do innego wniosku. Wynika on zarówno z przytoczonych tu analiz, jak i z oczywistego braku elementów koniecznych dla powstania takiej szkoły naukowej. Gdzie odnaleźć można deklaracje programowe nowego paradygmatu, prace wzorcowe, podręczniki prezentujące dla niego

${ }^{33}$ C. Leszczyńska, Polska polityka pieniężna i walutowa w latach 1924-1936, Warszawa 2013.

${ }^{34} \mathrm{~W}$. Pacho, Stagnacja gospodarcza $i$ innowacje techniczne $w$ okresie przedindustrialnym, Warszawa 2013.

${ }^{35}$ Co zreszta charakterystyczne, Rafał Matera nie wspomina nawet o wydanej niedawno pracy Boldizzoniego i zawartej w niej krytyce kliometrii. Jak zreszta słusznie zauważył Michał Kopczyński, uwagi włoskiego historyka, wcale zresztą w czambuł metod statystycznych nie potępiające, a miejscami idące wręcz $\mathrm{w}$ przeciwnym kierunku, bo dotyczące intensyfikacji prac nad nowymi zbiorami danych, nie zapowiadaja mimo wszystko przełomu w historiografii światowej i przez większość badaczy, w każdym razie z kluczowych ośrodków, zostaną zapewne zignorowane; por. F. Boldizzoni, The Poverty of Clio. Resurrecting Economic History, Princeton 2011; M. Kopczyński, Utracony świat Francesco Boldizzoniego, PH, t. 105, 2014, nr 3, s. 494-499. 
specyficzne pytania i metody badawcze? O ile naukowcy poprzednich pokoleń publikacje tego typu przygotowali, czego najlepszym przykładem sa Problemy $i$ metody historii gospodarczej Witolda Kuli, żaden współczesny antykwantytatywny historyk gospodarczy takiego wysiłku się nie podjał. Trudno zreszta podejrzewać, że praca tego typu kiedykolwiek powstanie, skoro zadanie takie wymaga dysponowania świadomościa teoretyczna i metodologiczna - czyli tym, czego nam dziś najbardziej brakuje i czego nie zastapia nawet setki niepowiązanych ze soba prac szczegółowych. Odnieść można wrażenie, że wiele z nich mogłoby być zakończone konkluzją napisaną niegdyś przez cytowanego już Józefa Rollego, który stosując metody statystyczne, nie potrafił dopasować do nich teorii: „Skończyłem. Wniosków z mej pracy nie wyprowadzam, do torowania dróg nowych nie mam pretensyi" 36 .

Nasze wystapienie nie było atakiem na środowisko, ale raczej diagnoza, według nas, złej kondycji badań nad historią gospodarcza, odwrotnie proporcjonalnej do obserwowanego samozadowolenia badaczy. Choć bowiem prawie połowa polskich instytutów historii ma w swym składzie katedry bądź zakłady historii gospodarczej (zwykle zresztą w powiązaniu z innymi terminami np. „,statystyki”, „demografii historycznej” itd.), to uwaga większości z nich poświęcona jest historii społecznej lub regionalnej. Skutkuje to nie tylko brakiem wyspecjalizowanych zespołów badawczych, ale też zwyczajnej dyskusji naukowej, ścierania się poglądów, uczenia się w oparciu o kontakt z innymi historykami ${ }^{37}$. W takiej sytuacji trudno jest mówić o nowoczesnej dydaktyce przygotowujacej nowe pokolenie badaczy wyspecjalizowanych w dziejach gospodarczych. Nauczanie nielicznych osób tą problematyką zainteresowanych sprowadza się często do oczekiwania, że powtarzać będa oni metody swych promotorów, a niekiedy wręcz niewolniczo je kopiować, bez innowacji czy sięgania po inne wzorce. System taki prowadzi z każdą kolejną generacją do coraz większego zubożenia przekazu, gdzie, jak w głuchym telefonie, treści zostają uproszczone, zredukowane do bezsensownego bełkotu albo wręcz porzucone.

${ }^{36}$ J. Rolle, O dziedziczeniu obłakania, „Przegląd Lekarski” 28, 1889, nr 10, s. 125.

${ }^{37}$ Znaczenie takich czynników można dostrzec na przykładzie aktywnego środowiska polskich demografów historycznych, którzy pięć razy w roku uczestniczą w spotkaniach Zespołu (dawniej Sekcji) Demografii Historycznej Komitetu Nauk Demograficznych PAN. Podobne gremium mające stanowić forum współpracy historyków gospodarczych - Komisja Historii Gospodarczej Komitetu Nauk Historycznych PAN - już od lat się nie zbiera i nie jest już nawet wykazywana na oficjalnej liście tego typu zespołów. 


\section{Bibliografia}

Klasztor $w$ gospodarce średniowiecznej $i$ nowożytnej, red. M. Derwich, Wroclaw 2013.

Kochanowicz J., Sosnowska A., Historia gospodarcza polski przedrozbiorowej - porzucone terytorium, RDSG, t. 71, 2011, s. 7-32.

Kowalczyk R., Rozwój przemystu ciężkiego w Królestwie Polskim w latach 1877-1914, Warszawa 2013.

Kula W., Problemy i metody historii gospodarczej, Warszawa 1963.

Myszczyszyn J., Wpływ kolei żelaznych na wzrost gospodarczy Niemiec (1840-1913), Łódź 2013.

Szymański J., Nauki pomocnicze historii, wyd. 6, Warszawa 2005.

Di Vaio G., Weisdorf J., Ranking Economic History Journals. A Citation-Based Impact Factor Analysis, „Cliometrica” 4, 2010, nr 1, s. 1-17.

Żabiński Z., Biologiczny wskaźnik siły nabywczej pieniadza, RGSG, t. 20, 1958, s. $37-51$.

Piotr Guzowski

Radosław Poniat

"That in the age of numbers, numbers only can be turned to for supporting one's propositions" - once more on the Polish studies of economic history

(Summary)

The authors, in referring to the paper written by Rafał Matera and published in this issue, argue that good studies from the field of economic history should 1) offer analyses informed by a social and economic theory; 2) make use of comparative methods, including as an advisable option the quantification of a series of data; 3) create or rely on specialized databases. Through the analysis of a number of works, the authors show that present-day Polish economic historians often fail to meet the requirements outlined above, thus making Polish historiography lag increasingly behind the historiography of other countries.

Key words: quantitative methods, economic history, methodology 